Karolina CHURSKA-NOWAK

Wyższa Szkoła Nauk Humanistycznych i Dziennikarstwa, Poznań

Łukasz ORYLSKI

Uniwersytet Gdański

\title{
The Boundaries between the Religious and the Secular on the Polish Political Scene
}

\section{Religion vs politics - a process of secularization of the sacred and sacralization of the profane.}

\begin{abstract}
basic purpose of this article is to analyze the relations between reliAgion and politics. A lot of similarities and analogies can be recognized in this area, one can observe a process of a mutual interference of those spheres. A basic thesis, enabling an acceptance of secular rituals is that about a society secularization, understood as a transfer of religious content to a secular sphere. The researcher can find a strict connection between secularization and desacralization, which are the consequence of a deep emancipation of modern society from religious institutions. This process results: in the sphere of economy-in development of capitalism, in the sphere of politics - in division between the state and the church, and in the sphere of culture - in a process of laicization of educational system and the autonomy of artistic and scientific activity ${ }^{1}$.

A great variety of definitions, applications of that term, a number of secularization ideas can be found. In general, however, it is recognized as a historic process, meaning a loss (inside a certain social order) of - a domination of religious institutions, religious activity, as well as religious way of thinking which will be substituted by the competitive secular forms-as science, politics, economy and administration ${ }^{2}$. It should be emphasized that secularization does not mean desacralization, demitologization or deritualization. In each sphere, even in a secular one, an element of religious logic exists. Despite of the fact to what extent desacralization pro-

1 E. Rothenbuhler, Komunikacja medialna: od rozmowy rodzinnej do ceremonii medialnej, Kraków 2003, s. 51.

2 Ibidem, s. 146-151.
\end{abstract}


cess is advanced, the way of people's thinking and behavior is unwittingly immersed in the aura of religion" ${ }^{3}$. As Cliford Geertz wrote: "In the political center of every society we can find the ruling elite as well as the aggregation of symbolic forms, which legitimize their rule. It does not matter if they were chosen in the democratic or nondemocratic way, or how deep divisions exist between them, they simply give reason of their power and their activity in the categories of stories, ceremonies, insignias, accessories, which are succeeded or established"4.

Also a democratic system does not mean the automatic desacralization, just the opposite, the most interesting process is the quick revival of political sacrum, denied by rationalistic critique ${ }^{5}$. Secularization gives rise to new rituals and by no means deletes them: myths, symbols and rituals (till now reserved for religion) are transferred to other domains, also to a sphere of politics ${ }^{6}$.

Obviously, their form remains unchanged, they fulfill similar functions, they meet analogue requirements; they simply touch different contents - not religious but secular ones. The sacral elements still appear in certain objects, formulas, forms, institutions. These modern sanctities are laid on four basic levels including mythical and ritual aspects. Those are: the level of the myth maintenance, the level of the wild sacrum and the ideo-political level. In this moment we should add, that Raymond Aron was the first person who was writing about a civic religion as a doctrine, which was present (in the hearts of modern people), replacing the idea of mankind salvation by the ideal social order in the future ${ }^{7}$.

Politics against the other domains is very susceptible for myths, ceremonies and symbols to survive. It is connected with a majority of human activities, conflicts inclusive. So we should not be surprised by the fact, that politics tends to replace religion - the highest principle of social life - to become a laic sacrum carrier. This is the exact meaning of secularization process - the politics and the state are not already based on religion, but the politics became (in some sense) the religion of the state. This replacement is not definite because the faith and the political hopes will be,

3 M. Eliade, Sacrum i profanum: o istocie religijności, Warszawa 1996, s. 48.

4 C. Geertz, Centers, kings and charyzma: Reflections on the symbolic power, in: Culture and its creators, ed. J. B. David, T. N. Clark, Chicago 1977, p. 152-153.

5 S. Filipowicz, Mit i spektakl władzy, Warszawa 1998, s. 166.

6 See: D. Kertzer, Ritual, politics and Power, New Haven 1998, p. 6.

7 J. Maisseneuve, Rytuały dawne $i$ wspótczesne, Gdańsk 1995, s. 51-53. 
sooner or later, denied by facts, despite of the symbolic support of laic liturgies and secular rituals directly connected with the state.

Politically tinged ceremonies and rituals deserve a particular note according to a kind of displacement of certain values from religious ceremonies. This process causes a greater intensity of experiences and emotions (at being continuously changed political meaning). A mythical element is present even in the most pragmatic political activity. There are two very important aspects of this problem: "a religious experience must be considered in a secularized society life - the second one - politics (particularly a democratic one) should be practiced as a kind of unusual, uncommon, ceremonial communication, adapted to the requirements of ceremony as well as to the needs of efficient and proficient communication" ${ }^{8}$.

The division into two separate spheres (a political and religious one) seems to be highly artificial. On the one hand we can indicate the analogies in the mechanisms of religious and political spheres, on the other hand there are many points where both spheres interfere (religious threads appear in politics and political ones influence the Church or even the Church is purposely involved in politics). So, on one hand, a secularization of sacrum sphere ${ }^{9}$ follows, on the other hand, a profanum sphere is sacralized. In this article we try to analyze these two levels. At a general (form) level we accept the analogy between religion and politics (a transfer of sacral elements into politics - the process of sacrum secularization), but in micro scale, at the lower (content) level, a number of religious threads appear and are used by politics to create political divisions, to fight political opponent. In this meaning there exist a process of using authorities, myths and religious symbols in a sphere of politics, and we can call it a process of profanum sacralization.

Concerning this first statement, at a more general level, we can indicate certain similarities between religion and politics. It can be observed at several levels:

a) Although politics enters all domains of modern society activities it remains something separated from everyday sphere. Marked by a ritual domain, by myths it must, first of all influence a sphere of emotions and symbols. It is also determined by certain fixed forms, places and the time of public practice. Such interference of politics into an every-

8 E. Rothenbuhler, op. cit., s. 126.

9 See: E. Durkheim, Elementarne formy życia religijnego, Warszawa 1990, passim. 
day sphere has got its unique institutionalized character. "A distance between politics, politicians and everyday sphere is expected to be associated with a distance between God and the confessor" ${ }^{\prime 10}$ (an inaccessible, separated sphere - attainable only in holy time, by myths and rituals);

b) in a political calendar, some enclaves of thinking and of activity in religious categories can be recognized; due to a converse of a dead time and an activity time, a sacral and a secular one (elections and electoral campaigns are holidays in a democratic calendar and religious holidays in a religious time) this political calendar assumes a nonlinearity of the time ${ }^{11}$. A common faith is renewed in a religious life, religious values and ideas are worshiped...In political life, certain ideals and sanctities are honored, common beliefs are renewed, democratic myths (of freedom, choice, sovereignty of people) are celebrated due to realized in regular intervals rituals;

c) faith is a very important element of both spheres: religion and politics. In a sense, each authority (even a democratic one) acts in a similar way as religion does, basing on a principle of an unreflective acceptance and faith. Frankly speaking, the authority nowadays is (as a long time ago) "good or bad (in a social reception), just later coming from God or democratic elections" $"$.

A political authority means a domination over symbols. These symbols are the main means of attaining and maintaining a political force. The elements of symbolism, used in politics, are derived from a religious sphere and there are, (first of all): myths, rituals and symbols ${ }^{13}$. Collective myths and political rituals play the roles, reserved in primitive societies for myths and religious or magic rituals. Mythical stories and ritual events allow participants to take part in a serious life (la vie serieuse in the meaning of Emile Durkheim), no matter how we define it and whether it sends us to the questions recognized (by participants) as political or religious ones ${ }^{14}$. Each society, even a democratic one, has got its own mythology, which defines its roots and origin, and the system of rituals which sanctifies the

10 S. Filipowicz, op. cit., s. 53.

11 P. Braud, Rozkosze demokracji, Warszawa 1995, s. 47-50.

12 T. Biernat, Legitymizacja władzy politycznej. Elementy teorii, Toruń 1999, s. 128 .

13 See P. Braud, op. cit., s. 17-19.

14 E. Rothenbuhler, op. cit., s. 113. 
existed norms. In this way the anthropological theory, created for the use of religious and ritual research, is also very helpful in the political studies.

\section{The process of secularization and sacralization in Poland}

We can be observed, a process of sacrum secularization and a process of weakening a role of religion even in Poland, where a democratic order is being built, new values and myths are strengthen. Tradition, arising in a very difficult time of approaching democracy in Poland is, for certain degree, a calculated, cultural phenomenon. It consists, not only of myths, rituals and symbols, quasi-holy texts but also of institutions interfering a political life. A system transformation required a political change and attaching a society to a new hierarchy of purposes and values. However, all these regulations create a compact system based upon symbolic and mythodological bases of democracy. A creation of a new democratic coherence requires some ideological "house-work" and a rejection of the ideologies associated, in Poland, with national and religious traditions. A success of consolidation of democracy in each country depends upon the ability of coherence of the traditions of the past with a new "cultural and political idiom"15. This way has just begun in Poland and has lasted since 1989, a process of secularization and creating a new "political religion" has been proceeding.

On the other hand some religious threads are used in micro scale to create the axes of political divisions. A present political discourse is in Poland an unique game, related to a ritual, based both on parliamentary solutions and an institutionalization of a conflict in a political life. This statement applies to a parliamentary ritual (a division for government and opposition; a processes of coalitions creation; negotiations with members of coalitions; parliamentary voting) as well as to a ritual performing strictly defined roles, imposed by axes of social, ideological and historical divisions, deriving from their place on the traditional continuum of rightism and leftism. Politicians, party-representatives perform these roles, as a drama and a script of a democratic fight in Polish political discourse require. In that meaning, such questions as: an attitude towards European integration, attitude towards religion or communist past become a very

15 V. Perez-Diaz, Powrót społeczeństwa obywatelskiego w Hiszpanii, Kraków 1996, s. $15-17$. 
efficient means to fight political opponents. On this ground a process of profanum sacralization is being performed in Poland. Religious trains appear in a current political activity, moral authorities support party campaigns and a religious symbolism is present in, a widely understood, advertising and marketing activity ${ }^{16}$. In this moment it should be marked that even in the economical sphere we can observe a lot of phenomenas which are characteristic for the sacrum domain, in this meaning we can analyze an existence of sacral elements (myths, holy-texts, institutions, definitions, formulas) in the contemporary economical theory and practice.

As far as the chronological order is concerned, in the Polish society, the tendencies to sacralise the profane became visible much earlier and had deeper influences than the process of secularization of the profane. The genesis of the former is connected with the period of non-existence of an independent Polish state between 1795 and 1918. During that time in the area of public discourse, the synthesis of national and religious content has taken place. The Catholic confession has differed Polish people both from the inhabitants of Russia (mostly Orthodox) and Prussia (mostly Protestant). The political culture of a local gentry was dominated by strong individualistic attitudes and a rather unsophisticated vision of freedom that were one of the major sources of a long-lasting crisis and the future collapse of the Polish state. After Poland lost the national sovereignty, no critical reflection about the reasons of this event has been made by the society. Poland was described as an innocent victim, "the Christ of nations". Only a small group of historians, known as "the Cracov school", has payed attention to the anachronic character of Polish political culture and the weakness of the public administration ${ }^{17}$. During that time, the papacy strongly condemned the Polish national uprising. The high clergy tended to be rather opportunistic in their relations with the occupational governments, while the parish priests did much to keep the Poles from assimilating. During the last years of the $19^{\text {th }}$ century, when the modern political orientations - the socialists and the national democrats - was being formed, the attitudes toward religion and the church became one of the key

16 M. Jeziński, Marketing polityczny a procesy akulturacyjne. Przypadek III Rzeczpospolitej, Toruń 2004, s. 114-115.

17 See: A. Bocheński, Dzieje gtupoty w Polsce. Pamflety dziejopisarskie, Warszawa 1994; J. Szujski, O fatszywej historii jako mistrzyni fałszywej polityki: rozprawy $i$ artykuly, Warszawa 1991. 
factors of such division. For the national democrats, religion was in the first place the background by which the Poles could be consolidated and also the source of the attitudes promoted by this political camp, that is sense of order and moral rigorism, whereas the socialists treated the church as an institution interested in preventing any social reforms. This division lasted until the beginning of the Second World War. Due to the mentioned synthesis of the national and religious identity and also the sceptical attitude of the clergy toward the capitalist economy, the Christian Democracy movement in the classical meaning of this term never gained much support.

After 1945, when the communist left seized power in Poland, the position of the Church became very similar to the one before 1918. The ecumenical hierarchy was consider to be representative of the vast majority of Poles as far as the relations with an official government were concerned. Between 1945 and 1976, the Catholic church was the only independent social actor that had influence in each social group. It has to be emphasized that the dissenters from the communist party, who became the first opposition circle, were almost as opposed to the church as the party itself. The radical change of the approach of so-called laic left was connected with the perception of two books - Rodowody niepokornych ("The Genealogy of the Unhumble") by Bogdan Cywiński and Kościót, lewica, dialog (English edition entitled "The Church and the Left") by Adam Michnik. In the former, the author emphasized the difference between two models of the Catholic church relations with the state, both of which were manifested in the ancient Rome. According to the author, the Constantinian church is structurally connected with the state and legitimate its politics while the Julianic one does not: "Despite its spiritual power never express the full solidarity with the society [...]. Not possessing any political influences, the church does not take the existence of any other centers of spiritual or intellectual integration of the society into consideration [...]. During the conflict with the secular government this institution would like to act alone, without partners, with whom it does not feel any solidarity"18. In the book written by Michnik ${ }^{19}$, a program of cooperation between the political opposition and the church was formulated. The ground for such an activity was protecting human and citizen rights. A few years later the

18 B. Cywiński, Rodowody niepokornych, Warszawa 1996, s. 71-72.

19 A. Michnik, Kościót, lewica, dialog, Paryż 1977. 
first strictly right political groups were found. In their programs the mentioned synthesis of religious and national consciousness can be found. As a consequence, it is justified to make a statement, that even though opposition groups were varied in their approach to religion, no one of these can be called antireligious or even anticlerical. The program of the "Solidarity" trade union, as far as economic issues are concerned, can be described as socialist or even syndicalist. Much attention has been given to the mass attachment to the Christian values, as well as to the Church itself ${ }^{20}$. Many priests were involved in the opposition activity, although the higher clergy have kept some distance from it. According to the research made by $\mathrm{K}$. Kosela more than half of the opposition election committees were located in the areas that belong to the parishes ${ }^{21}$.

The first serious conflict between the hierarchy and the supporters of the laic character of the state was connected with establishing religious education in public schools. Many people, even the ones who previously sang in the chant: "We want God in book, and in school", did not accepted the fact that the decision was implemented as the Minister of Education administrative act, instead of a bill. The beginning of the 90's was also the time that the engagement of clergy in political decisions seemed to be most visible. In one of the pastoral letters from 1990, written by bishop Józef Michalik such words can be found: "It should not be said, that an attitude of the religious indifference, agnosticism or atheism, does not influence the decision for whom to vote. Only the people having strong conscience are able to serve their community in a proper way"22. Two years later, cardinal Józef Glemp, in those days the primate of Poland, pointed out that: "We want to serve the nation as we have done before and no one is allowed to teach us how to do that. We understand the nation and we want to serve it in a way that we find the best",23.

20 See: S. Kowalski, Krytyka solidarnościowego rozumu: studium z socjologii myślenia politycznego, Warszawa 1990; A. Touraine, Solidarność 1980-1981, Warszawa 1989.

${ }^{21}$ K. Koseła, Katolicyzm w kampanii przed wyborami czerwcowymi, w: Wyniki badań, wyniki wyborów 4 czerwca 1989 roku, red. L. Kolarska-Bobińska, P. Łukasiewicz, Warszawa 1990, s. 124.

22 Quoted by J. Gowin, Kościół w czasach wolności 1989-1999, Kraków 1999, s. 52.

23 Quoted by I. Borowik, Religia $i$ Kościót a społeczeństwo obywatelskie $w$ procesie demokratycznej transformacji na przykładzie Polski, w: J. Baniak, Katolicyzm polski na przełomie wieków. Teologiczny, instytucjonalny $i$ wspólnotowy wymiar Kościoła, Poznań 2002, s. 81. 
The genesis of the "cold war" between the Catholic church hierarchy and the laic intelligentsia is strongly connected with the reluctance of the former to the model of the privatization of the religious beliefs ${ }^{24}$. However, it should be also emphasized that the latter used to judge the public engagement of the church using opportunistic criteria. When the hierarchy has supported the liberal values it's voice was very positively valuated by the former laic left, but each time when the statements were critical to liberalism, the Church was accused of being too much involved into politics $^{25}$.

The process of the secularization of the sacred in the Polish political discourse, manifest itself in the huge probability, that a model of religiousness that belong to the individual, will also affect the political affiliation and even cultural preferences. It seems to be justified to distinguish three major orientations, which are expressed both by the clergy and lay followers. The proposed typology is a widen version of the one created previously by Jarosław Gowin ${ }^{26}$.

\section{a) The "open" Catholicism}

- inspired by teaching of The Second Vatican Council, as well as the philosophy of personalism;

- open to an interdenominational and cross- religion dialogue;

- emphasize of the value of individual responsibility and freedom as the elements of the doctrine;

- critical attitude to the ritual dimension of religion and emphasizing the links between the religious and national identity;

- critical approach to Polish history (also the church history) and cultural heritage;

- affirmation of the evolutionary character of political transition after 1989;

- support of integration with the European Union;

- political affiliation can be called moderately liberal, in some cases it is social liberalism, preference to the parliamentary political system;

- moderately critical approach to the moral rigorism of the church hierarchy (especially in the area of "the politics of life" and sexual ethic).

24 See: J. Casanova, Religie publiczne w nowoczesnym świecie, Kraków 2005, s. 188.

25 J. Gowin, op. cit., s. 48-49.

26 J. Gowin, op. cit., s. 333-336. 


\section{b) The "integral" Catholicism}

- balance between opening to the challenges of modernity and criticism of axiological relativism, it's aim can be called "modernization in the name of traditional values";

- democracy is accepted mostly at it's procedural dimension, while the philosophical fundaments (e.g. the religious neutrality of the state) are being criticized;

- moderate support for Poland joining EU, described as "euro-realism"; reluctance for any engagement of the EU institutions at the "sphere of values", it's activity should be limited to the economic cooperation; the idea of "Europe of the Homelands";

- connections with the heritage of the democratic opposition groups acting before 1989 that has not defined themselves as "the laic left", strong anticommunism;

- the evolutionary character of political transition is being generally accepted, but not affirmated;

- the need of strong executive government and the concept of political rationality (in contrast with the "closed" Catholicism) is emphasized;

- much attention is put to the media communication.

\section{c) The "closed" Catholicism}

- the manicheic vision of social reality and fatalistic approach to history;

- any form of liberalism is considered to be a disguised form of totalitarianism;

- the past is very much valuated, although it is treated in an ahistorical way; religion has very close ties with the national identity, the universal dimension of the further is not very important;

- the fundament of religiousness is not the conscious reflection, but the devotion of the followers;

- the modern world is considered to be a seat of danger, and is treated both with fear and aggression;

- especially the representatives of the symbolic elites and the supporters of the "open Catholicism" used to be seen as enemies - the "hidden communist" or "Polish speaking citizens, not Poles", there are some of them even inside the Church hierarchy and they are known by name (the former senator has accused one of the bishops considered to be friendly to dialogue with non-believers of a "postmodernist indoctrination", not rarely the elements of conspiracy theories and anti-Semitic attitudes can be observe; 
- reluctance both to capitalism and the European Union, they are considered to be "anti-Christian". The alternative to them are: the idea of "economic independence" and "pan-Slavic cooperation";

- the need of charismatic leadership is widely expressed; and the law system should strictly reflect the Christian axiology;

- the approach to the communist system is complex, although it is verbally neglected in a very strong way, the social policy is valuated, what is more many prominent supporters of the "closed Catholicism" used to be the members of the Christian organizations that cooperated with the communist government.

It should be noted that the symbolic elites of the "integral Catholicism" very often show their reluctance to the public statements of "the closed Catholics" although when the discussed issue focused on ethic issues (e.g. abortion law) or the controversial issues in the national history (e.g. the massacre of Jewish citizens in Jedwabne village, during the Second World War) it is not easy to distinguish the statements of these two parts of the public opinion ${ }^{27}$. The similar alliance could be observed when "the closed Catholics" were very radically criticised by the vast majority of the public opinion (e.g. in case of the conflict upon the presence of the cross symbol at the area of the former Nazi concentration camp in Auschwitz) ${ }^{28}$.

While the Polish political discourse is being analised, also an important element of secularization of the sacred can be observed. The political opponents are treated as the religious enemies or even the metaphysical incarnation of evil. As a consequence, no boundaries between the secular and the holy are needed. To quote the former MP Jan Łopuszański "We want Poland to recognise Christ as it's King. This is the duty not only of the Holy Church but also the state government and the whole society". Many right wing parties as well as the "Solidarity" trade union, were denying the law of establishing the new state constitution by the democratically elected parliament. The reason for such a statement was that the parliamentary majority belonged to the left-wing party, which has transformed from the communist one eight years before. The approach of the clergy to the problem of directly mentioning the God's name in the consti-

27 See: M. Chałubiński, Polityka i aborcja, Warszawa 1994; J. Gądek, Wokót "Strachu”: dyskusja o ksiażce J. T. Grossa, Kraków 2006.

28 See texts quoted in: Spór o Polskę 1989-99. Wybór tekstów prasowych, red. P. Śpiewak, Warszawa 2000, s. 510-517. 
tution preamble was changing into the one represented by the "closed Catholicism". In 1993 the joint commission of the Episcopate and the minority denominations representatives pointed out that the constitutional regulations will be obligatory to all the citizens instead of their religious identity and. As a consequence mentioning God's name in the constitutional preamble can divide society. Three years later the Episcopate supported not only the Invocatio Dei (the preamble with God's name) but also the idea of the superiority of the natural law behind the state one and defined the source of the government as "the Polish nation" instead of "the state citizens" 29 .

The process of sacralisation of profane can be observed even without any engagement of the ecclesial hierarchy at the political scene. Many statements of Law and Justice Party can be described as the examples of the previously mentioned process. Even the name of the party is associated with religious beliefs. "He loves law and justice, He punishes the bad people" - this is a quote from the Biblical Book of David. The discourse created by the prominent members of Law and Justice and it's supporters from the circle of the symbolic elites connected with this party presents the Polish reality in an apocalyptical way ${ }^{30}$. In 2003 Jarosław Kaczyński, the party chairman said: "The present form of our state could not and can not play a positive role in a process of nation building. Instead it petrifies the status quo, in which weakness and constant parceling out the state structures are the guarantees of it's stability. This system in an excellent way unites the lack of justice with lack of any ideals, what also means serious limitation of altruistic motivation in social life. The power of this system is huge. The disintegration affects the whole nation, as well as smaller communities, it is omnipotent" ${ }^{\prime 31}$. The demanded shape of the future is described as the form of the Final Judgment. The division of political scene is considered to be grounded upon very strong historical fundaments that implies using the binary oppositions.

29 “Wyższe prawo nad konstytucja”, stanowisko Rady Stałej Konferencji Episkopatu Polski, "Gazeta Wyborcza", 16.02.1997, s. 4.

30 Ł. Michoń, O dialektyce rytualnej polityków Prawa i Sprawiedliwości, w: Mity, rytuały $i$ symbole we współczesnej polityce. Szkice z antropologii polityki, red. B. Szklarski, Warszawa 2008, s. 176-204.

31 Quoted in: Ł. Orylski, Evolution of the political discourse in Poland between August 2005 and September 2007, "Studia Kulturowe" 2008, nr 1, s. 22-34. 
It should be emphasised that the boundaries between the religious and secular sphere in the Polish political discourse still used to be fluent. Nevertheless since the beginning of the present century a process of their stabilization can be observed. The historic circumstances has been conductive both to the process of the secularization of the sacred (the example of which was playing the non-religious social roles by the Catholic clergy), and sacralization of the profane, (that was manifested in the tendency to treat the political opponent as religious enemy).

Contrary to the widely known thesis, the change of the perception of the social activity of the dominant Church by the vast majority of Poles does not seem to have a revolutionary character. It should be taken into consideration that the Polish religiosity is to large extend the strong factor of social identity while not being the source of individual spiritual experiences. This fact can be illustrated by the researches of theological awareness, for example according to Piwowarski, only the $49 \%$ of respondents living in cities believe in the existence of hell, while $93 \%$ of them accept the dogma of the Immaculate Conception ${ }^{32}$. Before 1989, the clergy did not require much from the people from their lay supporters in the campaign for democratization of a public sphere, as far as theological consciousness or even private morality were concerned ${ }^{33}$.

It is justified to make a statement that the attitudes toward the church were to large extend determined by the tendencies to the social orientation which was called by Reykowski a hierarchical collectivism ${ }^{34}$. In such orientation, the people possessing the lower social position are responsible for their acts before people that have higher one, while the latter are responsible for the condition of the former. While the communist government did not have the strong social legitimisation, the church may be considered by people that manifest just mentioned orientation as the quasi-government before which they were responsible. After the democratic transformation, the individual costs of socially sanctioned affiliation with the Catholic church became much higher, what have to caused mass objection. The lack of understanding of the clear church statements

32 W. Piwowarski, Wartości życia codziennego, w: Religijność Polaków 1991-1998, red. W. Zdaniewicz, Warszawa 2001, s. 189-201.

33 J. Mariański, Kościół katolicki w Polsce a życie społeczne, Lublin 2005.

34 J. Reykowski, Ukryte założenia normatywne jako osiowy składnik mentalności, w: J. Reykowski, J. Koralewicz, M. Ziółkowski, Orientacje społeczne jako element mentalności, Poznań 1990, s. 46. 
in many important social issues, as well as many serious mistakes made by the clergy during expressing such attitudes, are determined by the fact that the dichotomy between public and private sphere is perceiving as an absolute.

The sphere called by Offe "a non-institutional politics sphere" is not clearly defined in a mass consciousness ${ }^{35}$. In the countries with high degree of political culture, the mentioned sphere is the domain of new social movements that mostly have left-wing roots. In the Polish reality, when the social democratic, former communist, party has for many years after 1989 played the role of a conservative party in the political system ${ }^{36}$. Moreover, it has to a large extend represent the interests of the incumbents of economic transformation, the political contestation has the radical right-wing character and is often connected with "closed Catholicism"37.

As it has been shown in this article, the boundaries between religious and non-religious contents of Polish public discourse seem to be very liquid. Also, it is not easy to distinguish the two processes defined in the theoretical part of this work. Although nowadays the influence of the institutional Catholic church is much weaker than it was during the nineties, it has been replaced by the activity of the politically engaged laic followers. It should be emphasized that the new fields of conflict between religious and secular spheres were opened during the last months, e.g. the issue of the artificial conception (in vitro procedure). The line of division, as far as the approach to this issue is concerned, goes across the political parties and their parliamentary cocuses. After the catastrophe of the presidential plane at $10^{\text {th }}$ April 2010, with many prominent members of political elites on board it became obvious how liquid the mentioned boundaries are. Many examples of secularization of sacrum sphere as well as the opposite process in the political discourse after this tragedy can be seen. On the one hand, many representatives of the Catholic clergy consider the interpretation of this event in terms of religious symbols (the fatal accident happened one day before the Sunday of God's Mercy, during the time of Easter's octave and one week after the fifth anniversary of the death of

35 C. Offe, Nowe ruchy spoleczne: przekraczanie granic polityki instytucjonalnej, w: Władza i społeczeństwo. Antologia tekstów z zakresu socjologii polityki, red. J. Szczupaczyński, Warszawa 1995, s. 226.

36 B. Łagowski, Duch i bezduszność Trzeciej Rzeczpospolitej, Kraków 2007, s. 147 .

37 See: J. Staniszkis, Postkomunizm: próba opisu, Gdańsk 2001. 
John Paul II) as well as in context of national martyrdom (Poland as "Christ of nations"). On the other, politicians tend to treat the mentioned tragedy as the fundament of their own philosophy of history which is used as a tool of political marketing during the presidential campaign.

The very important factor of today's (June 2010) reality is the polarization of the previously mentioned models of religiosity strongly connected with political affiliations. The interpretations of the catastrophe itself and it's political consequence given by the supporters of "open Catholicism" are very close to the analysis given by the commentators which are distant or even reluctant to the Church institution. The authors of "Tygodnik Powszechny" express their hopes for the national reconciliation ${ }^{38}$ but also their concern connected with the monopolization of the national mourning by the politicians of Law and Justice ${ }^{39}$ as well as the disturbance of constitutional boundaries between church and state during the funeral ceremony of Lech Kaczyński ${ }^{40}$. Meanwhile, the boundaries between the "closed Catholicism" and the "integral" one became almost impossible to recognize, as in every critical moment. The only visible difference between them is that the former is concentrated on proving the Russian conspiracy ${ }^{41}$ while the supporters of the latter interpret the tragic accident as the Providence's memento for Poland which is getting more and more laicized but also the chance to build the new meta-political "republican community" 42 . It seems that the influence that the totally unpredictable tragedy near Smoleńsk does have on Polish political scene, does strengthen our thesis formulated in December 2008, although it is almost impossible to predict how the boundaries between religious and secular will look after the presidential elections.

38 W. Bonowicz, Nie ma ich tu, "Tygodnik Powszechny", 13.04. 2010, Internet edition, www.tygodnik.onet.pl.

39 B. de Barbaro, Żałoba nadużyta, "Tygodnik Powszechny", 19.04.2010, Internet edition, www.tygodnik.onet.pl.

40 T. Sławek, Coraz dalej; A. Chwalba, Panteon czy nekropilia, "Tygodnik Powszechny" 19.04.2010, Internet edition, www.tygodnik.onet.pl.

41 For example during many programs of Radio Maryja ("Rozmowy niedokończone"), available as audio files at www.radiomaryja.pl.

42 See: B. Radziejewski, Na progu republikańskiego odrodzenia, "Rzeczy Wspólne" 2010, nr 1, s. 5-15; texts quoted in: A. Bielik-Robson, Tanato-mesjano-faszyzm. O ostatnich odsłonach polskiej symboliki mesjańskiej, w: Żałoba. Antologia "Krytyki Politycznej", Warszawa 2010, s. 206-213. 


\section{Bibliography}

Barbaro de B., Żałoba nadużyta, "Tygodnik Powszechny”, 19.04.2010, Internet edition, www.tygodnik.onet.pl.

Biernat T., Legitymizacja władzy politycznej. Elementy teorii, Torun 1999.

Bielik-Robson A., Tanato - mesjano - faszyzm. O ostatnich odsłonach polskiej symboliki mesjańskiej, w: Żałoba. Antologia “Krytyki Politycznej”, Warszawa 2010, s. 206-213.

Bocheński A., Dzieje głupoty w Polsce. Pamflety dziejopisarskie, Warszawa 1994.

Bonowicz W., Nie ma ich tu, "Tygodnik Powszechny” 13.04.2010, Internet edition, www.tygodnik.onet.pl.

Borowik I., Religia i Kościól a społeczeństwo obywatelskie w procesie demokratycznej transformacji na przykładzie Polski, w: Katolicyzm polski na przełomie wieków. Teologiczny, instytucjonalny i wspólnotowy wymiar Kościoła, red. J. Baniak, Poznań 2002.

Casanova J., Religie publiczne w nowoczesnym świecie, Kraków 2005.

Chwalba A., Panteon czy nekropilia?, "Tygodnik Powszechny” 19.04.2010, Internet edition, www.tygodnik.onet.pl.

Culture and its creators, ed. J. B. David, T. N. Clark, Chicago 1997.

Cywiński B., Rodowody niepokornych, Warszawa 1996.

Durkheim E., Elementarne formy życia religijnego, Warszawa 1990.

Filipowicz S., Mit i spektakl władzy, Warszawa 1995.

Gowin J., Kościót w czasach wolności 1989-1999, Kraków 1999.

Graczyk R., Konstytucja dla Polski: tradycje, doświadczenia, spory, Kraków 1997.

Kertzer D. I., Ritual, politics and Power, New Haven 1988.

Koseła K., Katolicyzm w kampanii przed wyborami czerwcowymi, w: Wyniki badań, wyniki wyborów 4 czerwca 1989, red. L. Kolarska-Bobińska, P. Łukasiewicz, Warszawa 1990, s. 95-141.

Kowalski S., Krytyka solidarnościowego rozumu: studium z socjologii myślenia politycznego, Warszawa 1990.

Łagowski B., Duch i bezduszność Trzeciej Rzeczypospolitej, Kraków 2007.

Maissenneuve J., Rytuały dawne i współczesne, Gdańsk 1995.

Mariański J., Kościół katolicki w Polsce a życie społeczne, Lublin 2005.

Michnik A., Kościót, lewica, dialog, Paryż 1977.

Michoń Ł., O dialektyce rytualnej polityków Prawa i Sprawiedliwości, w: Mity, rytuaty i symbole we współczesnej polityce. Szkice z antropologii polityki, red. B. Szklarski, Warszawa 2008, s. 176-204.

Offe C., Nowe ruchy społeczne: przekraczanie granic polityki nieinstytucjonalnej, w: Polityka i aborcja, red. M. Chałubiński, Warszawa 1994. 
Władza i społeczeństwo. Antologia tekstów z zakresu socjologii polityki, red. J. Szczupaczyński, Warszawa 1995.

Orylski Ł., Evolution of the political discourse in Poland between August 2005 and September 2007, "Studia Kulturowe" 2008, nr 1, s. 22-34.

Pérez-Díaz V., Powrót społeczeństwa obywatelskiego w Hiszpanii, Kraków 1996.

Piwowarski W., Wartości życia codziennego, w: Religijność Polaków 1991-1998, red. W. Zdaniewicz, Warszawa 2001, s. 189 - 201.

Radziejewski B., Na progu republikańskiego odrodzenia, "Rzeczy Wspólne” 2010, nr 1, s. 5-15.

Reykowski J., Ukryte założenia normatywne jako osiowy składnik mentalności, w: Orientacje społeczne jako element mentalności, ed. J. Reykowski, J. Koralewicz, M. Ziołkowski, Poznań 1990, s. 11-53.

Rothenbuhler E., Komunikacja rytualna. Od rozmowy codziennej do ceremonii medialnej, Kraków 2003.

Sławek T., Coraz dalej, "Tygodnik Powszechny", 19.04.2010, Internet edition, www.tygodnik.onet.pl.

Spór o Polskę 1989-99, red. P. Śpiewak, Warszawa 2000.

Staniszkis J., Postkomunizm: próba opisu, Gdańsk 2001.

Szujski J., O fatszywej historii jako mistrzyni fatszywej polityki: rozprawy i artykuły, Warszawa 1991.

Touraine A., Solidarność 1980-1981: analiza ruchu społecznego, Warszawa 1989.

Wokót "Strachu”, dyskusja o książce J. T. Grossa, red. J. Gądek, Kraków 2006.

Wyższe prawo nad konstytucja, stanowisko Rady Stałej Konferencji Episkopatu Polski, "Gazeta Wyborcza", 16.02.1997, s. 4.

\section{Streszczenie}

Prezentowany tekst stanowi zmodyfikowaną wersję wystapienia wygłoszonego podczas międzynarodowej konferencji "Religion, identity and life courses", zorganizowanej przez Institute for the Studies of Religion in Central and Eastern Europe (ISORECA). Sympozjum odbyło się w grudniu 2008 w Collegium Medicum Uniwersytetu Jagiellońskiego. Artykuł poświęcony jest specyfice relacji między porządkiem sakralnym a świeckim w polskim systemie politycznym. Problematyka ujęta została w kontekście reprezentowanych w literaturze przedmiotu paradygmatów publicznego funkcjonowania religijności oraz uwarunkowań mających swe źródło w specyfice polskiej kultury politycznej. Wyodrębniono paralelne procesy sekularyzacji sacrum i sakralizacji profanum oraz typy afiliacji politycznej skorelowane z modelami polskiej religijności. Jak się wydaje, zaproponowane modele i konkluzje zachowują, a nawet wzmacniają swą aktualność w perspektywie politycznych reperkusji katastrofy lotniczej pod Smoleńskiem, a więc wydarzenia nieprzewidywalnego $\mathrm{w}$ ramach prognostycznej funkcji nauk politycznych. 
